\title{
Effects of Photoperiod and Temperature on Macrothallus Initiation in Dumontia contorta (Rhodophyta)
}

\author{
H. Rietema \\ Department of Systematic Botany, Biological Centre, University of Groningen, P.O. Box 14, 9750 AA Haren (Gr.),
} The Netherlands

\begin{abstract}
Gametophytic and sporophytic microthalli of Dumontia contorta from Isle of Man appear to persist indefinitely in the vegetative state at photoperiods of $14 \mathrm{~h}$ and longer, but form erect, branched, tubular macrothalli at photoperiods of $12 \mathrm{~h}$ or less. Responses of microthalli kept under different daylengths at 2,000 lux, and those of microthalli kept under daylength-adjusted light intensities, giving equal daily light doses, did not differ from one another. The critical daylength for this short-day response is approximately $12 \mathrm{~h}$. The response to short-day conditions was inhibited by a short white night-break of $0.25 \mathrm{~h}$ given in the middle of a $16 \mathrm{~h}$ dark period, irrespective of light intensity $(2,000$ or 180 lux $)$; this suggests a genuine photoperiodic response as known from flowering plants. However, a relatively large number of short-day cycles (at least 31) are required to produce some effect. Macrothalli formation involves 2 separate steps. The first step (induction of macrothallus initials) depends entirely on daylength, the second (development of initials into macrothalli) on both daylength and temperature. This was deduced from the fact that macrothallus initials were formed under shortday conditions irrespective of temperature $\left(4\right.$ to $\left.24^{\circ}\right)$, whereas macrothalli were formed from initials under short-day conditions but only at temperatures of $16^{\circ}$ (critical temperature) or lower. At $26^{\circ}$ microthalli died gradually. Like microthalli, macrothalli grow optimally at 16 to $18^{\circ}$. It follows, therefore, that macrothalli cannot be expected to grow from macrothallus initials above $16^{\circ}$ and under short-day conditions, since elongation of short cells in the filaments of macrothallus initials (start of macrothallus growth) would be blocked. Elongation of these cells was probably also blocked by longday conditions because macrothallus initials did not grow out after transfer of microthalli from shortday to long-day conditions at $12^{\circ}$
\end{abstract}

\section{INTRODUCTION}

The life history of the marine red alga Dumontia contorta (Dumontiaceae, Cryptonemiales) comprises isomorphic gametophytic and sporophytic phases. Carpospores and tetraspores produced by the gametophytic phase and sporophytic phase respectively, grow into crustose discs (microthalli) from which later tubular, branched, erect thalli (macrothalli) arise. The results of previous investigations on gametophytic plants indicate that the development of macrothalli from microthalli is affected by daylength and temperature (Rietema and Klein, 1981). Macrothalli sprouted from microthalli under short-day conditions and lower temperatures only. Under long-day conditions and higher temperatures the microthalli continued to grow as crusts. The development of macrothalli from crus- tose microthalli of the brown alga Petalonia fascia and Scytosiphon lomentaria is influenced by temperature and daylength in the same way (Wynne, 1969; Roeleveld et al., 1974; Dring and Lüning, 1975; Nakamura and Tatawaki, 1975). In Scytosiphon lomentaria the photoperiodic response is a genuine photoperiodic short-day response of the type characteristic of flowering plants (Dring and Lüning, 1975). The characteristics of such a response are: (1) The plants show a response if the daylength does not exceed a critical day-length; (2) the short-day response is inhibited if a short night-break is given in the middle of a relatively long dark period; (3) the plants can be induced by a relatively short exposure to short-day conditions; after transfer into non-inductive daylength conditions they still remain in the induced state (Terborgh and Thimann, 1964; Vince-Prue, 1975). The pre- 
sent investigation analyses in greater detail the influence of photoperiod and temperature on the formation of macrothalli from microthalli in both Dumontia gametophytes and sporophytes.

\section{MATERIAL AND METHODS}

Unialgal cultures of Dumontia contorta were established from spores released by plants collected on the Isle of Man (1979). The present experiments were conducted with spores released by cultured plants using techniques described previously (Rietema and Klein, 1981). Briefly these consisted of collecting released spores allowed to settle on glass squares cut from microscope slides. Glass squares with growing spores were kept separately for $5 \mathrm{wk}$ at $12^{\circ}$, long-day conditions $(16: \overline{8})$ and 2,000 lux in Petridishes (diameter $5 \mathrm{~cm} ; 4 \mathrm{~cm}$ high) filled with enriched seawater (Provasoli, 1968) and transferred thereafter to experimental conditions (Figs. 1, 4, 5, 6) as mentioned otherwise. The culture fluid was renewed every fortnight. The number of microthalli per glass square in these experiments varied from ca. 10 to 35 , and the number of microthalli exposed to each set of conditions amounted to 100 or more. Glass squares seeded too densely with spores were thinned out to avoid crowding when the microthallus discs were formed.

All experiments were done in culture cabinets (Fridina) with different temperature and daylengtth regimes. Light was emitted by white fluorescent tubes (Philips TL W/34; White de Luxe) and microthalli were kept at 2,000 lux and constant light doses so that the amount of light $(=$ photometer reading [lux] $\times$ photoperiod [h]) in any $24 \mathrm{~h}$ period was constant. This value amounted to 16,000 luxh. Only at photoperiods of 2 and $2.5 \mathrm{~h}$ was this daily light dose somewhat Iower. Temperature fluctuations in all experiments remained within $1.0 \mathrm{C}^{\circ}$, and all light values were $\pm 5 \%$.

To test the effect of a night-break treatment the dark period of $8: \overline{16}$ photoperiod was interrupted in the middle by a white light night-break of $0.25 \mathrm{~h}$. This light night-break had the same light intensity of 2,000 lux as the main photoperiod, or a lower intensity.

\section{RESULTS}

Effects of Photoperiod and Temperature on Development of Discoid Gametophytic Microthalli

Results of experiments with discoid microthalli obtained from tetraspores and kept at 9 different photoperiods are given in Fig. 1. Macrothallus development occurred only under short-day conditions

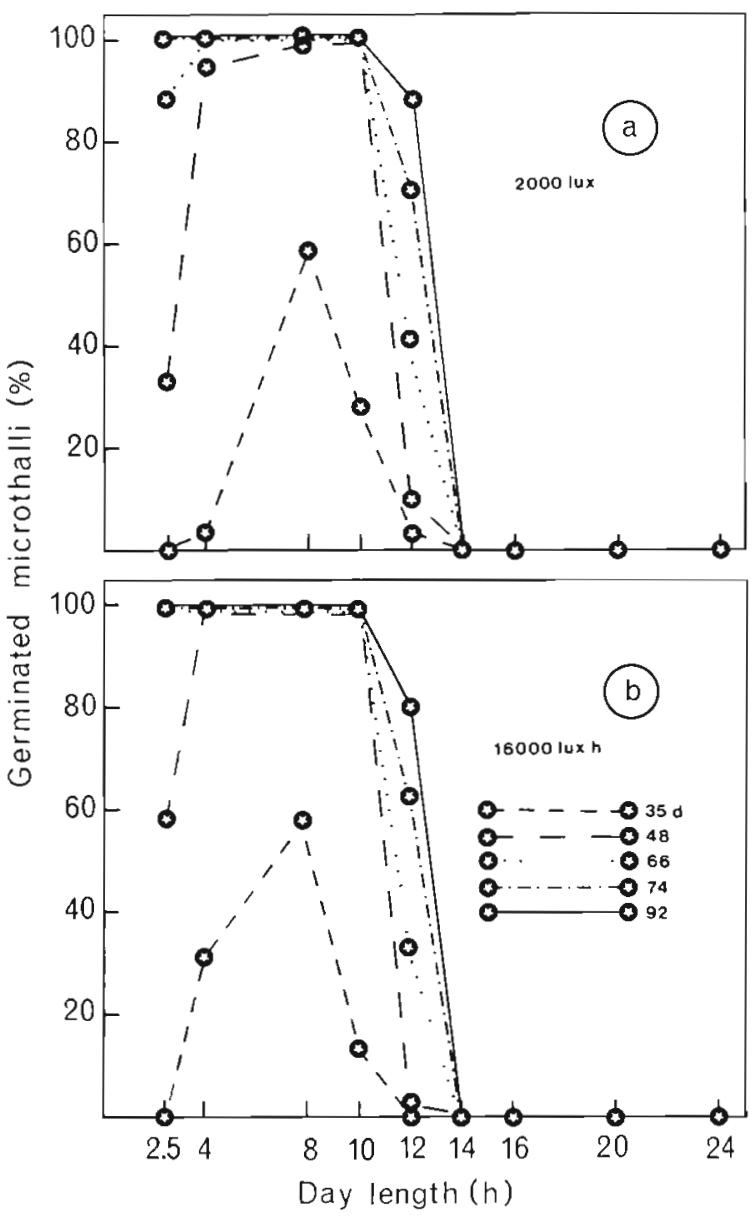

Fig. 1. Dumontia contorta. Development of $5 \mathrm{wk}$ old discoid, gametophytic microthalli at different daylengths and $12^{\circ}$ Percentages of microthalli $(n \geq 100)$ with macrothalli after 35 , $48,66,74$ and $92 \mathrm{~d}$, exposed to 2,000 lux (a) and to equal daily light doses (b)

$(4: \overline{20} ; 8: \overline{16} ; 10: \overline{14})$ in smaller numbers after a longer period of observation also at the intermediate daylength condition $(12: \overline{12})$ and at a photoperiod of $2.5: \overline{21.5}$. In these respects microthalli kept at a light intensity of 2,000 lux (Fig. 1a) did not differ from those kept at daylength-adjusted light intensities (Fig. 1b).

Qualitative differences between discoid microthalli kept for $10 \mathrm{wk}$ under long- and short-day conditions are shown in Fig. 2.

Macrothalli on $8 \cdot \mathrm{wk}$ old microthalli kept at a photoperiod of $4 h, 2,000$ lux and $12^{\circ}$ were cut off from their microthalli which were subsequently exposed to $16^{\circ}$, long-day conditions and 2,000 lux (i.e. summer-like conditions). No new macrothallus development occurred in these conditions within $12 \mathrm{wk}$. Microthalli transferred thereafter into $12^{\circ}$, short-day conditions developed macrothalli within $6 \mathrm{wk}$, however, microthalli transferred into $12^{\circ}$, long-day conditions remained crustose (Fig. 3). 

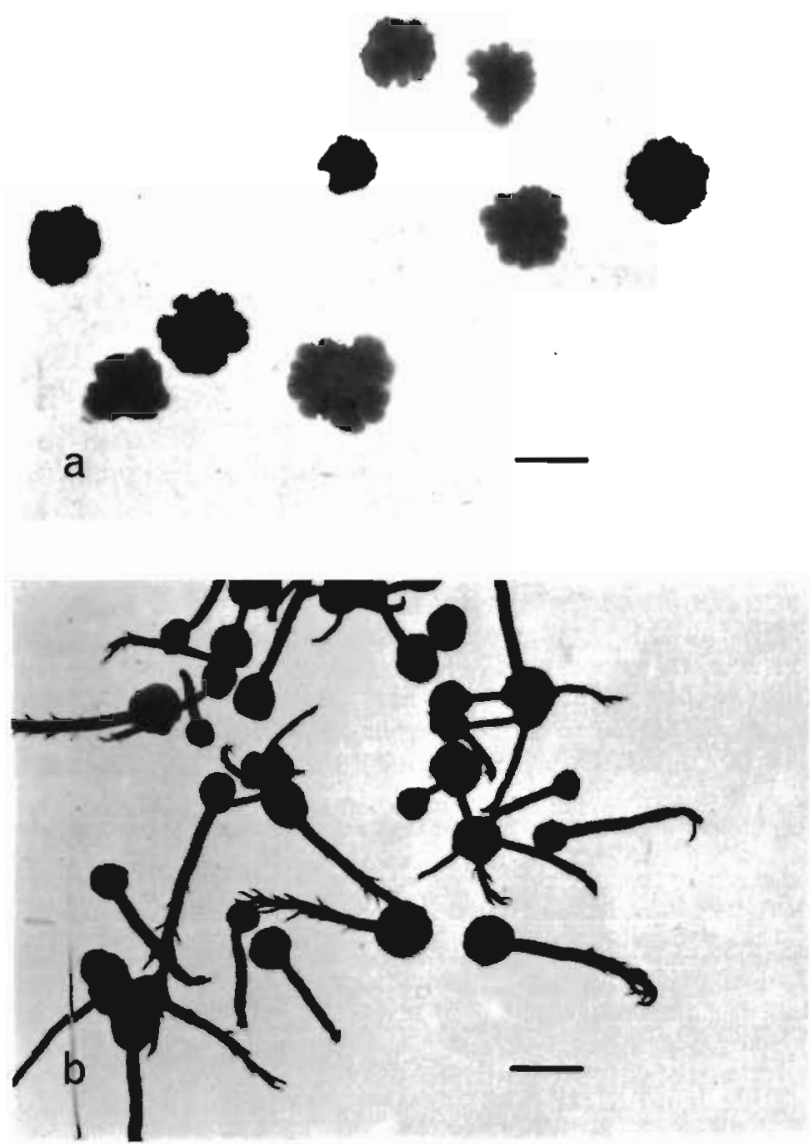

Fig. 2. Dumontia contorta. Photographs of cultures kept for 8 wk under long-day $(16: \overline{8}), 2,000$ lux and $12^{\circ}$ conditions (a) and short-day $(8 ; \overline{16}), 2,000$ lux and $12^{\circ}$ conditions (b). Scale bars $=2 \mathrm{~mm}$

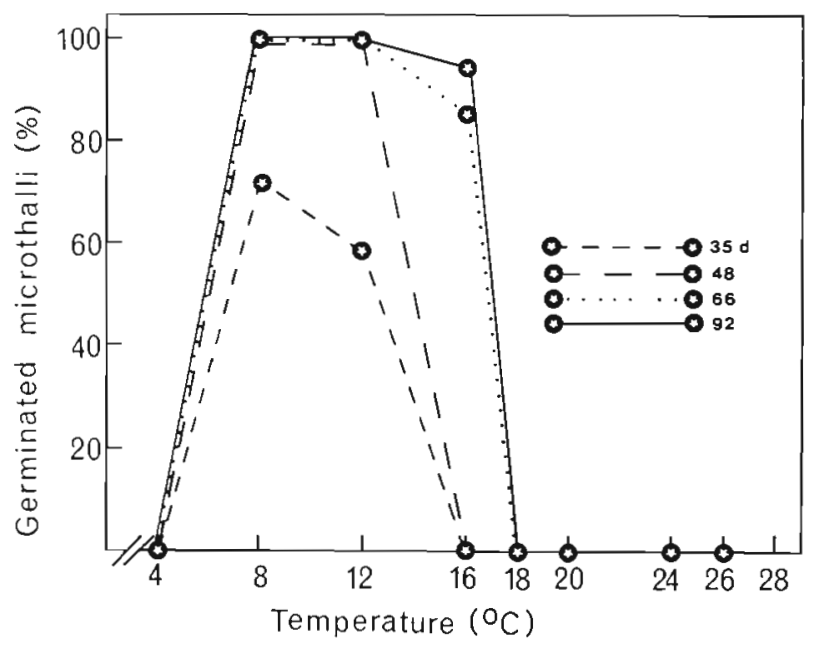

Fig. 4. Dumontia contorta. Development of $5 \mathrm{wk}$ old discoid, gametophytic microthalli; various temperatures, short-day $(8 ; \overline{16}), 2,000$ lux. Percentages of microthalli $(\mathrm{n} \geq 100)$ with macrothalli after $35,48,66$ and $92 \mathrm{~d}$
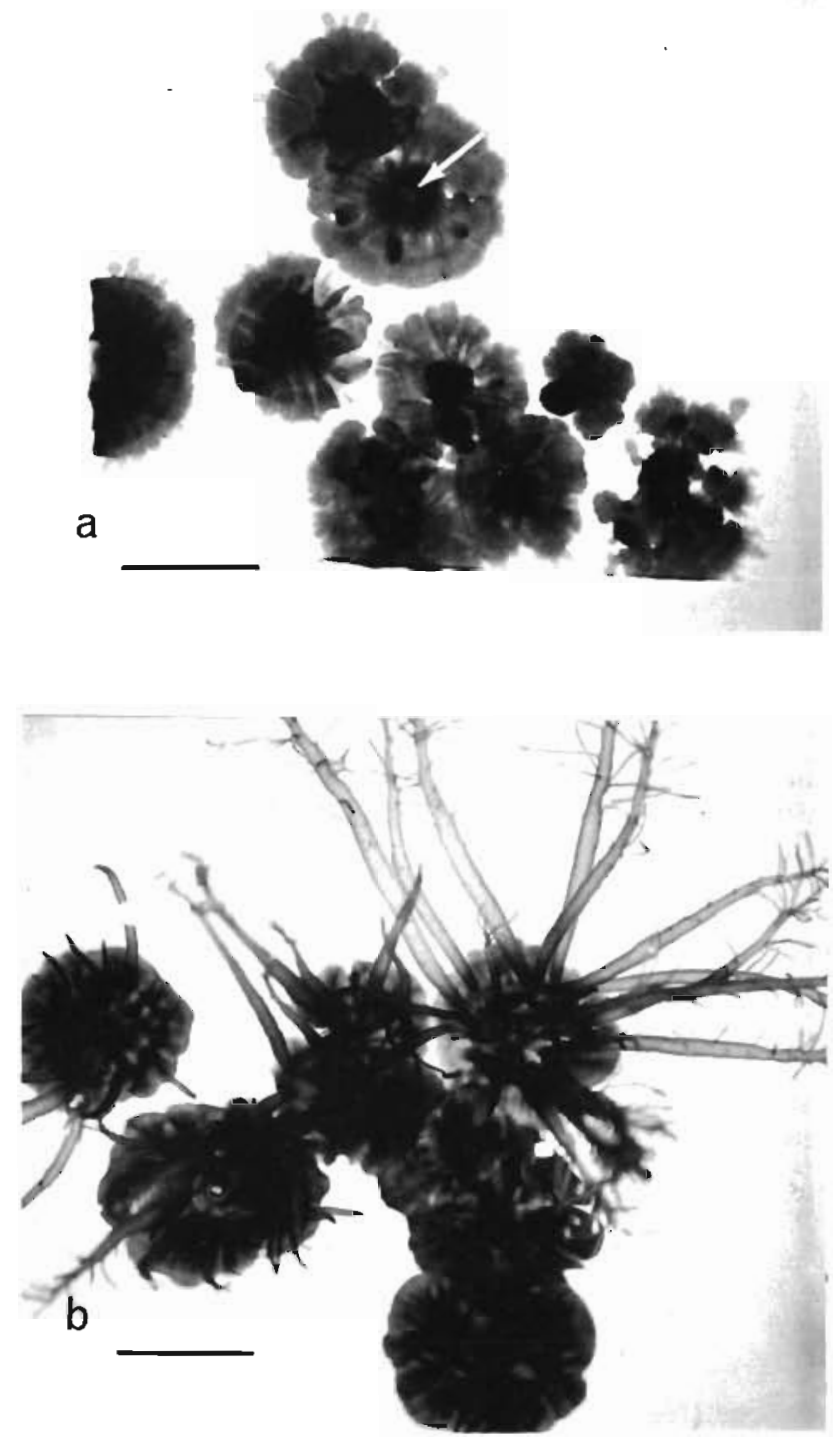

Fig. 3. Dumontia contorta. Photographs of cultures kept $10 \mathrm{wk}$ under long-day $(16: \overline{8}), 2,000$ lux and $12^{\circ}$ (a) and short-day $(8: \overline{16}) 2,000$ lux and $12^{\circ}$ (b). Pre-cultured $8 \mathrm{wk}$ under shortday, $12^{\circ}$ conditions (after which macrothalli were cut from microthalli), subsequently $12 \mathrm{wk}$ under long-day, $16^{\circ}$ conditions (= summer-like conditions). Arrow: scars of cut off macrothalli. Scale bars $=5 \mathrm{~mm}$

The results of experiments with microthalli kept at 8 different temperature regimes (Fig. 4) show that macrothallus development occurred at 8 and $12^{\circ}$, after a longer period also at $16^{\circ}$. No macrothallus development occurred at the lowest temperature $\left(4^{\circ}\right)$ and the higher temperatures $\left(18,20\right.$ and $\left.24^{\circ}\right)$ investigated. At $26^{\circ}$ the microthalli died gradually. Macrothallus initials visible as light coloured spots were formed under the same range of conditions as those on sporophytic microthalli (see below). 
Effects of Photoperiod and Temperature on the Development of Discoid Sporophytic Microthalli

The results of experiments with discoid microthalli grown from carpospores kept at 8 different photoperiods are given in Fig. 5. Macrothallus development occurred either under short-day conditions $(2: \overline{22}$; $4: \overline{20} ; 8: \overline{16}$ ) or, in small numbers, after a longer period under the intermediate daylength condition $(12: \overline{12})$. In these respects microthalli kept at a light intensity of 2,000 lux (Fig. 5a) did not differ from those kept at the daylength-adjusted light intensities (Fig. 5b). No macrothalli sprouted from microthalli kept at a photoperiod of $2 \mathrm{~h}$ and 2,000 lux, the daily light dose apparently being too low for sufficient photosynthesis.

The results of experiments with microthalli kept at 8 different temperature regimes are illustrated in Fig. 6. This figure shows that macrothallus development occurred at $4,8,12$ and $16^{\circ}$. The optimum temperature

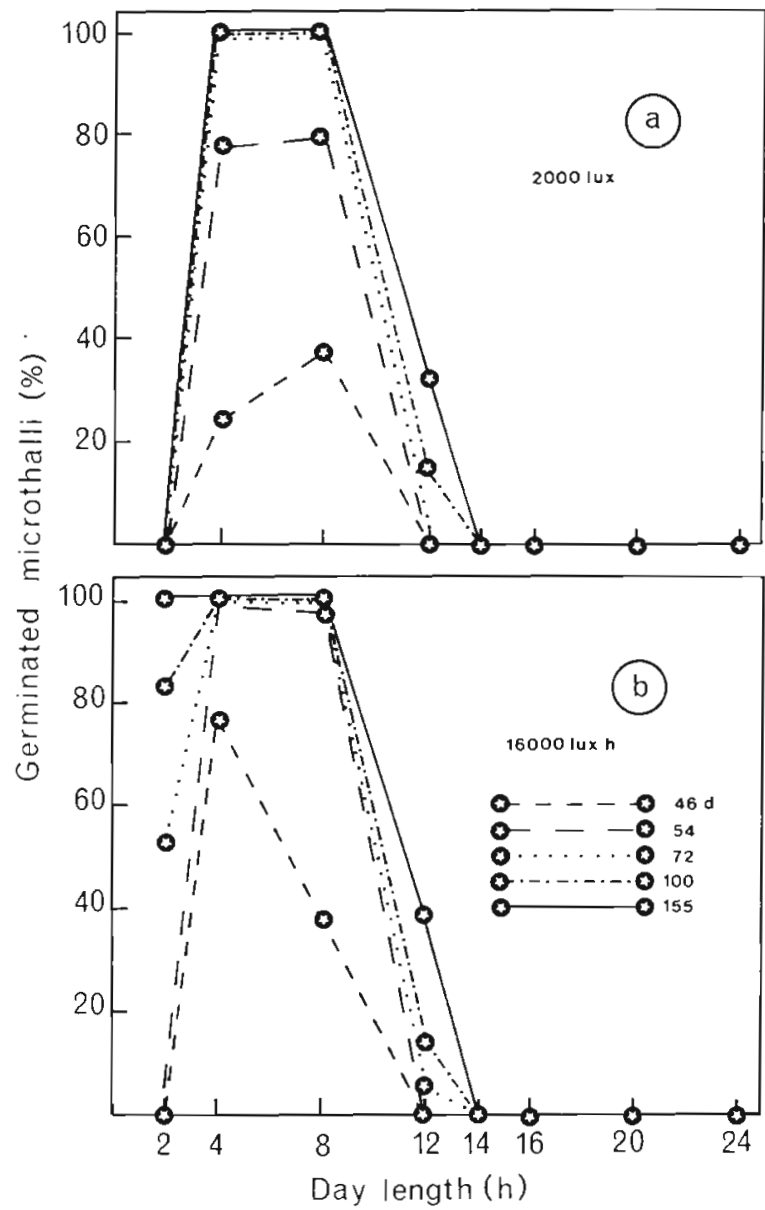

Fig. 5. Dumontia contorta. Development of 5 wh old discoid. sporophytic microthalli at different daylengths. Percentages of microthalli ( $n \geq 100$ ) with macrothalli after $46,54,72,100$ and $155 \mathrm{~d}$ and exposed to 2,000 lux (a) and to equal daily light doses (b)

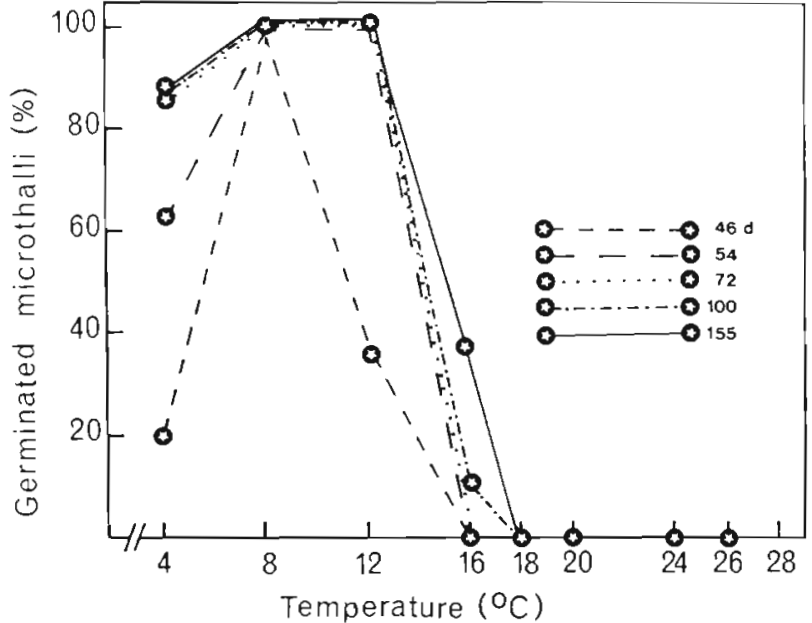

Fig. 6. Dumontia contorta. Development of 5 wk old discoid sporophytic microthalli; various temperatures, short-day $(8: \overline{16}), 2,000$ lux. Percentages of microthalli ( $n \geq 100$ ) with macrothalli after $46,54,72,100$ and $155 \mathrm{~d}$

range for the initiation of macrothalli from microthalli was 8 to $12^{\circ}$.

Appearance of macrothalli was always preceded by the appearance of light-coloured spots which represented initial stages of macrothalli (cf. Rietema and Klein, 1981; Fig. 7). Although under intermediate daylength conditions only a small number of microthalli germinated into macrothalli, all microthalli bore one to several light coloured spots $76 \mathrm{~d}$ after the start of the experiment. Sometimes light-coloured spots occurred at a photoperiod of $14 \mathrm{~h}$ but under this daylength regime never developed into macrothalli. These macrothallus initials did not occur on microthalli kept at a photoperiod of $16 \mathrm{~h}$ or longer.

All microthalli kept at $18^{\circ}$ and $20^{\circ}$ and short-day conditions $(8: \overline{16})$ bore $76 \mathrm{~d}$ after the start of the experiment, one to several macrothallus initials; some were also observed at $24^{\circ}$. However, microthalli kept at these temperature regimes never developed macrothalli. Transverse sections through discs with lightcoloured spots (macrothallus initials) showed that these were composed of bundles of erect filaments consisting of short cells (Fig. 8).

\section{Transfer of Sporophytic Microthalli from Short-Day Conditions into Long-Day Conditions}

In order to determine the number of short-day cycles sufficient for the initiation of macrothalli a large number of 5 -wk old microthalli were kept for a varying number of days under short-day conditions $(8: \overline{16})$, 2,000 lux and after that they were transferred to longday conditions $(16: \overline{8}), 2,000$ lux in portions of about 90 
a
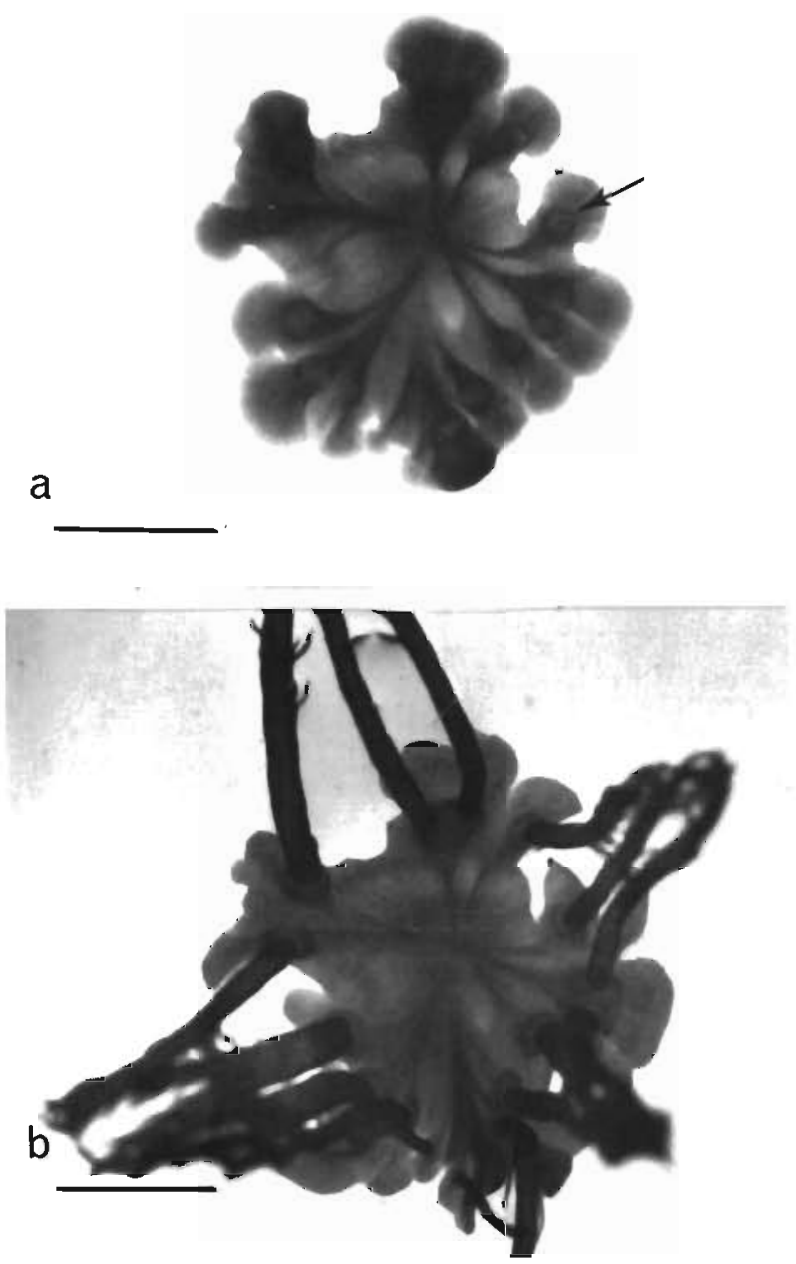

Fig. 7. Dumontia contorta. Microthallus grown in culture; $12^{\circ}$, short-day. (a) Microthallus with macrothallus initials visible as light-coloured spots. Arrow: incipient macrothallus. (b) Same microthallus 6 wk later Scale bars $=2.5 \mathrm{~mm}$

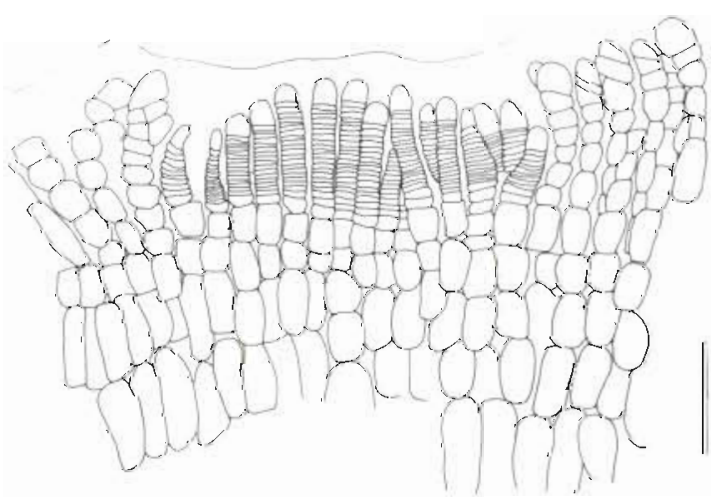

Fig. 8. Dumontia contorta. Section through disc $\left(12^{\circ}\right.$, shortday) with macrothallus initial (visible as light-coloured spot), composed of several primordia of axial filaments consisting of short cells. Scale bar $=50 \mu \mathrm{m}$

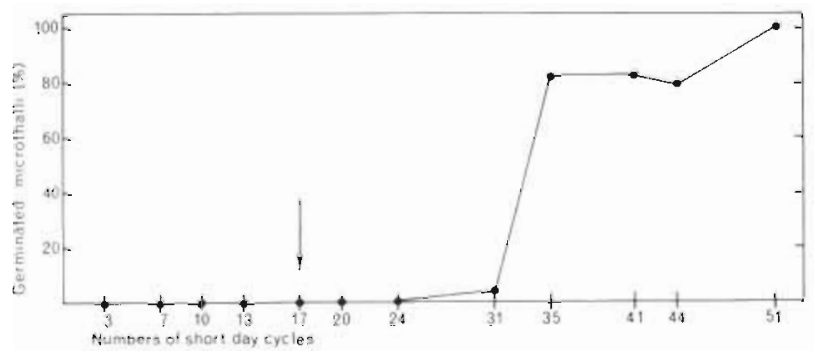

Fig. 9. Dumontia contorta. Sporophytic microthalli kept for a varying number of days under short-day $(8: \overline{16}), 2,000$ lux, $12^{\circ}$ conditions and subsequently transferred into long-day, 2,000 lux and $12^{\circ}$ conditions. Percentages: microthalli germinated into macrothalli $51 \mathrm{~d}$ after start of experiment. Arrow: time when first macrothallus initials were observed

microthalli in a large Petridish (diameter $10 \mathrm{~cm}$ ). The number of germinated microthalli in each culture was determined $51 \mathrm{~d}$ after start of the experiment. The results (Fig. 9) show that at least 31 short-day cycles were required to bring about some effect.

\section{Transfer of Sporophytic Microthalli from Intermedi- ate into Short- and Long-Day Conditions}

Microthalli kept for $100 \mathrm{~d}$ under intermediate daylengths $(12: \overline{12}), 12^{\circ}$ were transferred to short $(8: \overline{16})$ and long daylength $(16: \overline{8})$ conditions, $12^{\circ}$ or were kept as a control under the intermediate daylength conditions, 2,000 lux. Eight to 10 microthalli were kept under each experimental condition. At the moment of transfer the average number of macrothallus initials per microthallus (light spots) amounted to 7 . The results (Fig. 10) indicate no macrothallus development at all from microthalli under long daylength (Fig. 10A), a large increase of the average number of macrothalli per microthallus under short daylength (Fig. 10B), and a very slight increase under intermediate daylength (Fig. 10C) conditions. In the course of the experiment the average number of macrothallus initials decreased distinctly under short daylength and this occurred also under long daylength where the macrothallus initials vanished. Under intermediate daylength the number of initials amounted constantly to about 7 per microthallus.

Of the microthalli transferred into short-day conditions, the initials - laying in a concentric ring near the centre and formed under intermediate-day conditions - developed into macrothalli. 


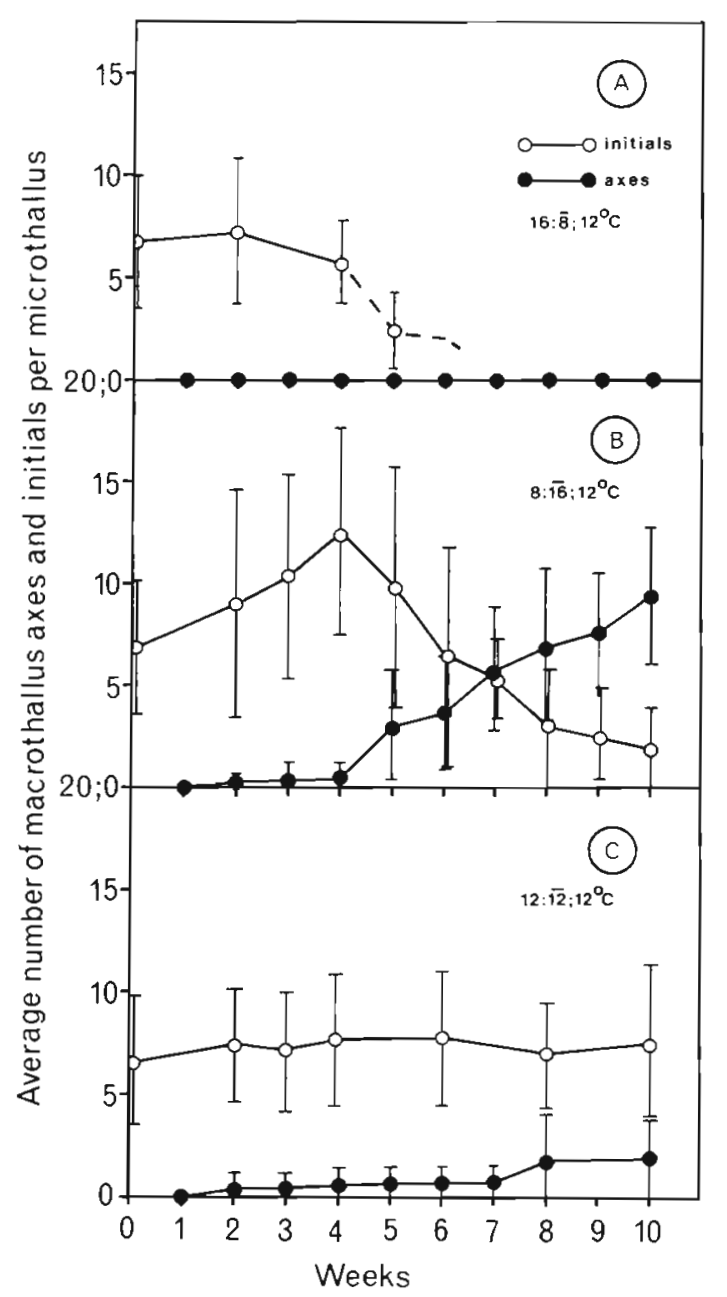

Fig. 10. Dumontia contorta. Production of macrothalli from macrothallus initials formed on microthalli pre-cultured for $100 \mathrm{~d}$ (intermediate daylength, 2,000 lux, $12^{\circ}$ ) subsequently transferred to long-day conditions (A), short-day conditions (B) or kept as control under intermediate daylength conditions (C), all at 2,000 lux and $12^{\circ}$. Open circles: average number of macrothallus initials per microthallus. Closed circles: ditto for macrothallus axes. Vertical bars: standard deviation. Number of microthalli per condition: ca. 8. Broken line: period of infrequent observations when the initials vanished

\section{Transfer of Sporophytic Microthalli from Higher to Lower Temperatures}

Microthalli kept for $86 \mathrm{~d}$ under $16^{\circ}$, short-day conditions $(8: \overline{16})$ were transferred to $12^{\circ}$, short-day $(8: \overline{16})$ or long-day $(16: \overline{8})$ conditions, 2,000 lux or were kept as a control under $16^{\circ}$ short-day conditions, 2,000 lux. Eight to 10 microthalli were kept under each condition. At the moment of transfer the average number of macrothallus initials per microthallus was about 10 . The results are given in Fig. 11. Macrothallus initials on the microthalli transferred to $12^{\circ}$ long-day conditions (Fig. 11A) gradually vanished. The difference between pre-

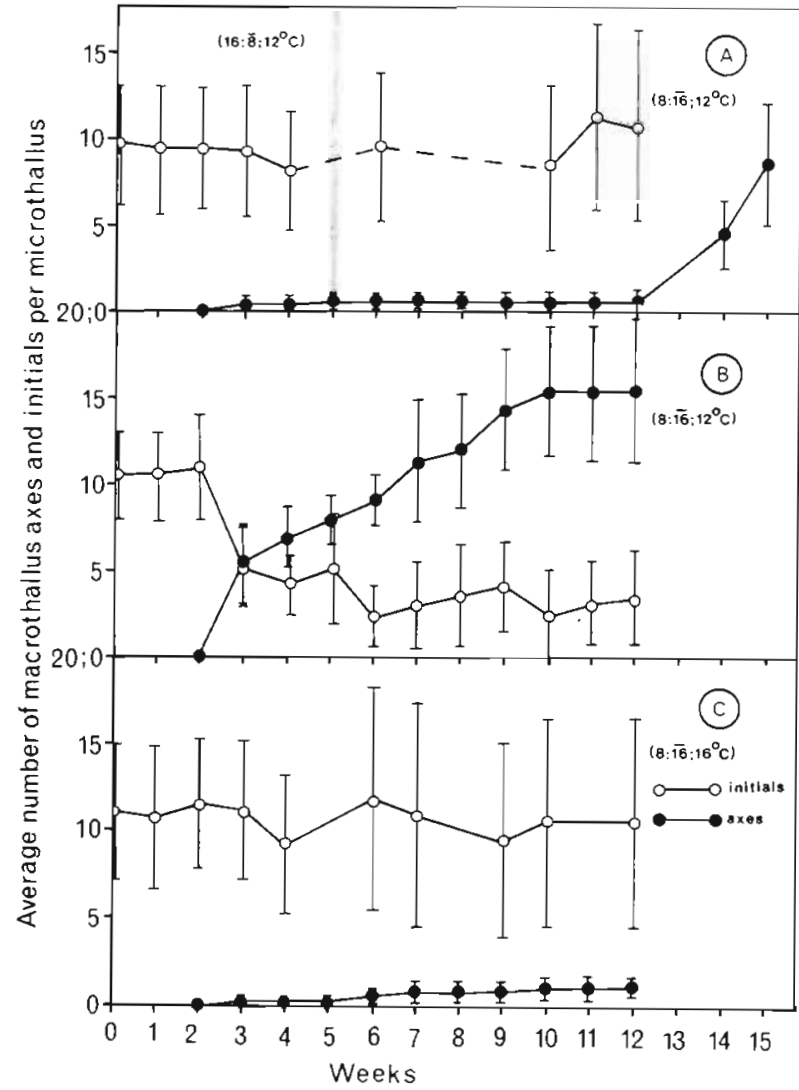

Fig. 11. Dumontia contorta. Production of macrothalli from macrothallus initials formed on microthalli pre-cultured for $86 \mathrm{~d}_{i}$ first $16^{\circ}$ short-day, 2,000 lux, then transferred to $12^{\circ}$, long-day conditions for $5 \mathrm{wk}$, and finally into $12^{\circ}$, short-day conditions (A), $12^{\circ}$, short-day conditions (B), or kept as control under $16^{\circ}$, short-day conditions (C), all at 2,000 lux. Open circles: average number of macrothallus initials per $\mathrm{mi}$ crothallus. Closed circles: ditto for macrothallus axes. Vertical bars: standard deviation. Number of microthalli per condition: ca. 10

sence (as a diminutive spot) and absence of an initial is often difficult to determine. Therefore between the 4 th and 10th wk after start of the experiment the initials were not counted regularly. However, the initials reappeared on exactly their original locations after transfer of these microthalli into $12^{\circ}$ short-day conditions (which occurred after the 5th wk) and subsequently developed into macrothalli. The results also indicate a distinct increase of the average number of macrothalli on microthalli transferred directly after start of the experiment into $12^{\circ}$, short-day conditions, whereas the average number of macrothallus initials per microthallus decreased (Fig. 11B). Under $16^{\circ}$, short-day conditions the average number of macrothalli and macrothallus initials per microthallus changed only slightly (Fig. 11C).

Macrothallus initials on microthalli kept under $18^{\circ}$ and $20^{\circ}$ short-day conditions also grew into macrothalli after transfer of microthalli to $12^{\circ}$, short-day conditions. 


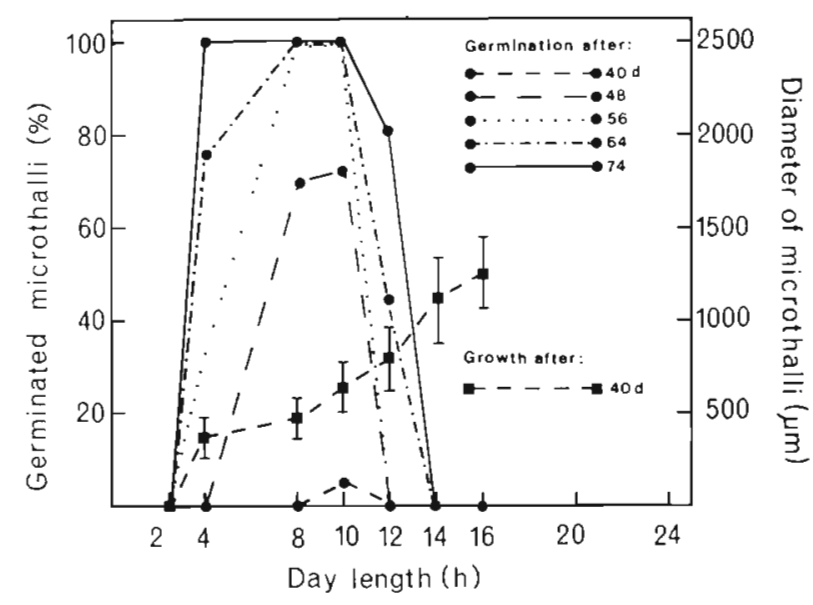

Fig. 12. Dumontia contorta. Germination rate (percentages of microthalli with macrothalli) and growth rate of microthalli (as diameter) grown from tetraspores transferred directly after release into different daylength regimes; $2,000 \mathrm{lux}, 12^{\circ}$. Percentages of microthalli ( $\mathrm{n}>50$ ) with macrothalli after 40,48 , 56,64 and $74 \mathrm{~d}$ (circles) and average diameter of microthalli (squares) after $40 \mathrm{~d}$. Vertical bars: standard deviation

\section{Effect of Photoperiod and Temperature on Growth Rates of Microthalli}

The influence of photoperiod on growth rates of microthalli was investigated by transferring tetraspores directly after release into the varying daylength regimes (Fig. 12). Growth rates of microthalli were determined by measuring their diameter. The results ((Fig. 12) suggest that growth rates of microthalli

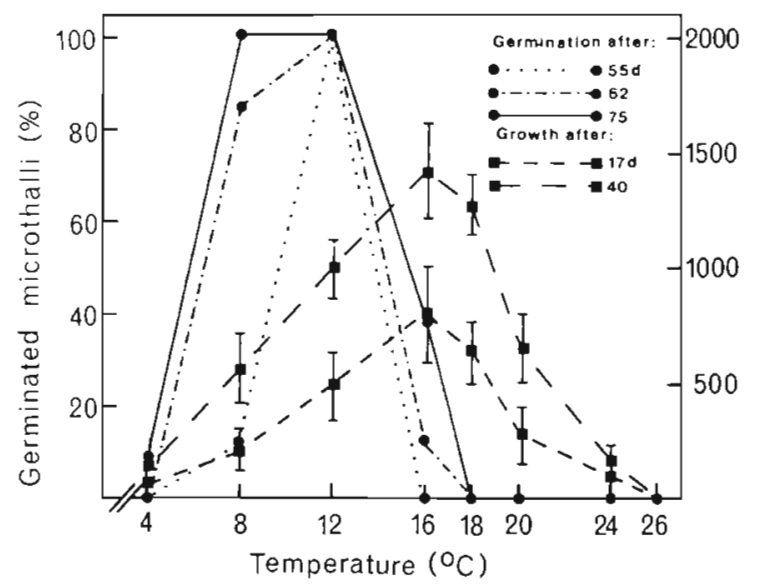

Fig. 13. Dumontia contorta. Germination rate (percentages of microthalli with macrothalli) and growth rate of microthalli (as diameter) grown from tetraspores transferred directly after release into different temperature regimes and short-day conditions $(8: \overline{16})$. Percentage of microthalli $(n>50)$ with macrothalli after 55,62 and $75 \mathrm{~d}$ (circles) and average diameter of microthalli (squares) after 17 and $40 \mathrm{~d}$. Vertical bars: standard deviation increased with increasing daylength. The largest microthalli were obtained under the longest daylength regimes investigated $(14: \overline{10} ; 16: \overline{8})$. Under these regimes macrothalli did not develop at all.

Macrothalli only sprouted from the smaller microthalli grown under short-day conditions $(4: \overline{20}$; $8: \overline{16} ; 10: \overline{14}$ ) and, after a longer period of observation, also under the intermediate daylength condition $(12: \overline{12})$.

The influence of temperature on the growth rate of microthalli was investigated by transferring tetraspores almost directly after release into the different temperature regimes (Fig. 13). The results suggest an optimum temperature for microthallus growth of 16 to $18^{\circ}$ and an optimum temperature of 8 to $12^{\circ}$ for the development of microthalli to macrothalli. No macrothallus development occurred at either the lowest temperature $\left(4^{\circ}\right)$ or the higher temperatures $(18,20$, $24^{\circ}$ ) investigated. At $26^{\circ}$ the spores died. Also in this experiment macrothallus initials were formed on all microthalli kept at 18 and $20^{\circ}$.

\section{Effect of Temperature on Growth Rates of Macrothalli}

The influence of temperature on the growth rates of macrothalli was investigated by exposing 15 small macrothalli - of about equal size and cut from microthalli - to $8,12,16,18$ and $20^{\circ}$ long-day conditions and 2,000 lux. Growth was measured as fresh and dry weight after $70 \mathrm{~d}$. The results (Table 1) indicate

Table 1. Dumontia contorta. Fresh and dry weight of 15 macrothalli of about the same age and size, kept for $70 \mathrm{~d}$ under 20 . $18,16,12$ and $8^{\circ} \mathrm{C}$, long-day, 2000 lux conditions

\begin{tabular}{|ccc|}
\hline $\begin{array}{c}\text { Temperature } \\
\left({ }^{\circ} \mathrm{C}\right)\end{array}$ & $\begin{array}{c}\text { Fresh weight } \\
(\mathrm{mg})\end{array}$ & $\begin{array}{c}\text { Dry weight } \\
(\mathrm{mg})\end{array}$ \\
\hline 20 & 414.2 & $61.1^{\circ}$ \\
18 & 754.0 & $79.0^{\circ}$ \\
16 & 614.7 & $84.0^{\circ}$ \\
12 & 291.6 & 59.3 \\
8 & 361.1 & 52.8 \\
& & \\
- Fertile plants & & \\
\hline
\end{tabular}

optimum growth at 16 and $18^{\circ}$. Fertile plants were observed at 20,18 and $16^{\circ}$ but not at the lower temperatures.

\section{Effect of Night-Break Treatment on the Development of Microthalli into Macrothalli}

The results of a short night-break treatment given in the middle of a $16 \mathrm{~h}$ dark period with white light, on 
Table 2. Dumontia contorta. Effect of night-break on the development of macrothalli from 5 wk old gametophytic microthalli

\begin{tabular}{|c|c|c|c|c|c|c|}
\hline \multirow{2}{*}{$\begin{array}{c}\text { Main photoperiod } \\
\text { (h) }\end{array}$} & \multirow{2}{*}{$\begin{array}{l}\text { Night-break treatment } \\
\text { (h) }\end{array}$} & \multirow[b]{2}{*}{ (specification) } & \multicolumn{4}{|c|}{$\%$ germinated microthalli after } \\
\hline & & & $40 \mathrm{~d}$ & $56 \mathrm{~d}$ & $74 \mathrm{~d}$ & $92 \mathrm{~d}$ \\
\hline 16 & - & - & 0 & 0 & 0 & 0 \\
\hline 8 & - & - & 93 & 100 & 100 & 100 \\
\hline 8 & 0.25 & $2000 \operatorname{lux}$ & 0 & 0 & $0^{\circ}$ & $0^{\circ}$ \\
\hline
\end{tabular}

Table 3. Dumontia contorta. Effect of night-break on development of macrothalli from 5 wk old sporophytic microthalli

\begin{tabular}{|c|c|c|c|c|c|c|}
\hline \multirow{2}{*}{$\begin{array}{l}\text { Main photoperiod } \\
\text { (h) }\end{array}$} & \multirow{2}{*}{$\begin{array}{l}\text { Night-break treatment } \\
\text { (h) }\end{array}$} & \multirow[b]{2}{*}{ (specification) } & \multicolumn{4}{|c|}{$\%$ germinated microthalli after } \\
\hline & & & $36 \mathrm{~d}$ & $44 \mathrm{~d}$ & $54 \mathrm{~d}$ & $100 \mathrm{~d}$ \\
\hline 16 & - & - & 0 & 0 & 0 & 0 \\
\hline 8 & - & - & 57.4 & 100 & 100 & 100 \\
\hline 8 & 0.25 & 1500 lux & 0 & 0 & 0 & 0 \\
\hline 8 & 0.25 & 180 lux & 0 & 0 & 0 & 0 \\
\hline
\end{tabular}

the growth of macrothalli from microthalli is shown in Tables 2 and 3 . Night-break treatments of $0.25 \mathrm{~h}$ with white light, suppressed the development of macrothalli and usually had the same effect as a long-day treatment. However, on some microthalli light coloured spots were observed and cross sections revealed initial stages of macrothalli. Such light coloured spots did not occur under long-day conditions so that a white night-break treatment did not precisely simulate longday conditions.

\section{DISCUSSION}

Responses of Dumontia concorta to different light and temperature regimes confirm our preliminary investigations in which we found that macrothalli sprouted from microthalli under short-day conditions and low temperatures (Rietema and Klein, 1981). The present results indicate that gametophytes (Figs. 1 and 4) and sporophytes (Figs. 5 and 6) do not differ appreciably from one another in this respect. This daylength effect was not brought about by lower daily light doses, since the responses both of microthalli kept in different daylength conditions at a light intensity of 2,000 lux and of those kept at the daylength-adjusted light intensities did not differ from one another. However, at a photoperiod of $2 \mathrm{~h}$ macrothallus development occurred only at the daylength-adjusted light intensity level, not at 2,000 lux. Probably at a photoperiod of $2 \mathrm{~h}$ and 2,000 lux the daily amount of light energy is too small for producing a photosynthetic surplus and consequently for macrothallus formation. For this reason also the formation of macrothalli from microthalli could be delayed at a photoperiod of $2 \mathrm{~h}$ at the daylength-adjusted light intensity and at a photoperiod of $2.5 \mathrm{~h} \mathrm{2,000} \mathrm{lux} \mathrm{and} \mathrm{at} \mathrm{the} \mathrm{daylength-adjusted} \mathrm{light}$ intensity. At a photoperiod of $12 \mathrm{~h}$ macrothallus development is also reduced and sometimes microthalli do not give off macrothalli at all. No macrothallus development occurs at all at a photoperiod of $14 \mathrm{~h}$ or longer. The large differences in response between short-day cultures $(4: \overline{20} ; 8: \overline{16} ; 10: \overline{14})$ and intermediate daylength cultures $(12: \overline{12})$, the absence of any response at daylengths of $14 \mathrm{~h}$ or longer, and the increase of the average number of macrothalli per microthallus after transfer of microthalli from the intermediate daylength condition into short daylength condition (Fig. 10) indicates a critical daylength for macrothallus 'induction' of approximately $12 \mathrm{~h}$.

Macrothallus development occurs at all temperature regimes investigated from 4 to $16^{\circ}$. At $4^{\circ}$, the development of macrothalli is delayed; at $16^{\circ}$ it is reduced. No macrothalli develop at $18^{\circ}$ or higher. The large differences in response between microthalli kept at low temperatures $\left(8^{\circ}\right.$ and $\left.12^{\circ}\right)$ and microthalli kept at $16^{\circ}$, the absence of macrothallus development at $18^{\circ}$ or higher, and the increase of the average number of macrothalli per microthallus after transfer of the microthalli from 16 into $12^{\circ}$ short-day condition (Fig. 11) suggest a critical temperature for erect macrothallus development of approximately $16^{\circ}$.

However, macrothallus initials were observed at all temperature regimes under which the microthalli survived (in combination with short daylengths), from 4 to $24^{\circ}$. These results suggest that the formation of macrothalli involves 2 separate steps: (1) Formation of macrothallus initials; (2) development of these initials 
into macrothalli. The first step is initiated by short photoperiods alone, whilst the second step is brought about by short photoperiods in conjunction with low temperatures. Therefore macrothallus initials on microthalli do not develop further after transfer from 'inductive' short-day conditions to 'non-inductive' long-day conditions (Figs. 10 and 11). In Dumontia contorta, macrothallus development could be suppressed by white light night-break treatment in the middle of the dark period (Tables 2 and 3). White light nightbreaks of $0.25 \mathrm{~h}$ and 2,000 lux were as effective as those of lower light intensities (1,500 or 180 lux). Therefore it is extremely unlikely that the effect of night-break treatment was caused by extra photosynthesis. Inhibition of erect macrothallus development from microthalli by a short night-break indicate that the photoperiodic response of $D$. contorta is a genuine photoperiodic response.

This is well known for flowering plants (Vince-Prue, 1975) and for the brown alga Scytosiphon lomentaria (Dring and Lüning, 1975). However, in Dumontia contorta a relatively large number of short-day cycles must be given before the development of macrothalli from microthalli will occur (Fig. 9).

The negligible differences in response between microthalli derived from spores transferred directly after release into different regimes of light and temperature (Figs. 12 and 13) and microthalli pre-cultured for $5 \mathrm{wk}$ under long-day conditions (Figs. 1, 4,5 and 6) suggest that perception of daylength takes place in both recently-and long-established microthalli. This is confirmed by an experiment with long-established microthalli which appeared to be capable of producing more than one generation of macrothalli under shortday conditions (Fig. 3).

The responses of Dumontia contorta microthalli to different daylength and temperature regimes show that macrothalli are only formed at low to moderate temperatures and under short-day conditions; this is reflected by the seasonal reappearance of $D$. contorta in autumn (Rosenvinge, 1909; Dunn, 1917; den Hartog, 1959; Kilar and Mathieson, 1978; Kristiansen and Pedersen, 1979). The present results indicate that daylength is the primary factor in the control of macrothallus development since macrothallus initials are formed under short-day conditions irrespective of temperature

Temperature appeared to be an additional factor in the control of macrothallus development and to prevent the development of macrothallus initials into macrothalli above $16^{\circ}$. The formation of macrothalli from microthalli in Dumontia contorta is influenced by temperature-daylength conditions in a way similar to that in Scytosiphon lomentaria (Dring and Lüning, 1975). Based on field data, Kilar and Mathieson (1978) believe that the growth of $D$. contorta is optimal at low temperatures $\left(<10^{\circ}\right)$. However, in the present study and this roughly agrees with observations by Fortes and Lüning (1980) - the optimum temperature for growth of $D$. contorta macrothalli appeared to be 16 to $18^{\circ}$ (Table 1 ), whilst macrothallus initials can develop into macrothalli only at temperatures $\leq 16^{\circ}$. Possibly the elongation of the short cells in young initials of $D$. contorta macrothalli (Fig. 8) is blocked in some way above $16^{\circ}$. Possibly, this can also be caused by longday conditions after transfer of microthalli from shortday conditions into long-day conditions (Figs. 10 and 11). Details of the development of macrothallus initials into macrothalli will be published later.

According to Lüning (1980) the main ecological significance of Scytosiphon lomentaria's photoperiodic response, which resembles the photoperiodic response of Dumontia contorta in many respects, lies in the fact that swarmers released by macrothalli in the summer are forced to develop into solid 'oversummering' crusts (solid crusts are formed in this species only at long-day conditions and relatively high temperatures). Spores released by $D$. contorta, however, develop into solid crusts irrespective of daylength conditions and temperature, although their fastest growth occurs at higher temperatures (16 and $18^{\circ}$; Fig. 13). Higher temperatures also promote the growth rate of $D$. contorta macrothalli, as well as the onset of reproductive maturation (Table 1). Higher temperatures promote growth of macrothalli also in the brown alga Desmotrichum undulatum, but here the largest macrothalli are formed at lower temperatures and relatively small macrothalli at higher temperatures; at higher temperatures vegetative growth is soon curtailed by intense formation of reproductive cells (Rietema and van den Hoek, 1981). Probably this also occurs in $D$. contorta. The daylength and temperature responses discussed above assure that macrothalli of $D$. contorta are produced during the cold season and thus develop into large plants.

Acknowledgements. I wish to thank Dr. A. M. Breeman and Professor Dr. C. van den Hoek for critically reading the manuscript and $\mathrm{A}$. ten Hoopen for valuable advice. Furthermore I wish to thank Mrs. Y. Butler for improvements in my English manuscript.

\section{LITERATURE CITED}

Dring, M. J., Lüning, K. (1975). A photoperiodic response mediated by blue light in the brown alga Scytosiphon lomentaria. Planta 125: 25-32

Dunn, G. A. (1917). Development of Dumontia filiformis. II Development of sexual plants and general discussion of results. Bot. Gaz. LXIII: 425-467

Fortes, M. D., Lüning, K. (1980). Growth rates of North Sea macroalgae in relation to temperature, irradiance and photoperiod. Helgoländer Meeresunters. 34; 15-29 
Hartog, C. den (1959). The epilithic algal communities occurring along the coast of the Netherlands, North-Holland Publishing Company, Amsterdam

Kilar, J. A., Mathieson, A. C. (1978), Ecological studies of the annual red alga Dumontia incrassata (O. F. Müller) Lamouroux. Botanica Mar. 21: 423-437

Kristiansen, Aa., Pedersen, P. M. (1979). Studies on life history and seasonal variation of Scytosiphon lomentaria (Fucophyceae, Scytosiphonales) in Denmark. Bot. Tidsskr. 74: $31-56$

Lüning, K. (1980). Control of algal life-history by daylength and temperature. In: Price, J. H., Irvine, D. E. G., Farnham, W. F. (eds.) The shore environment, Vol. 2, Ecosystems. Academic Press, London and New York

Nakamura, Y., Tatawaki, M. (1975). The life history of some species of the Scytosiphonales. Sci. Papers Inst. Algol. Res., Hokkaido Univ. 6: 57-93

Provasoli, L. (1968). Media and prospects for the cultivation of marine algae. In: Watanate, A., Hattori, A. (eds.) Cultures and collection of algae (Proceedings of U.S.-Japan conference, Hakano, Sept. 1966). Jap. Soc. Plant Physiol. 1968: $63-75$
Rietema, H., Hoek, C. van den (1981). The life history of Desmotrichum undulatum (Phaeophyceae) and its regulation by temperature and light conditions. Mar. Ecol. Prog. Ser. 4: 321-335

Rietema, H., Klein, A. W. O. (1981). Environmental control of the life cycle of Dumontia contorta (Rhodophyta) kept in culture. Mar. Ecol. Prog. Ser. 4: 23-29

Roeleveld, J. G., Duisterhof, M., Vroman, M. (1974). On the year cycle of Petalonia fascia in the Netherlands. Neth. J, Sea Res. 8: 410-426

Rosenvinge, L. K. (1909). The marine algae of Denmark, contributions to their natural history. Vol. I, Rhodophyceae. Danske Vidensk. Selsk. Skrifter 7. Raekke Naturvidens., og Mathem., Afd. VII, København

Terborgh, J., Thimann, K. (1964). Interactions between daylength and light intensity in the growth and chlorophyll content of Acetabularia crenulata. Planta 63: 83-98

Vince-Prue, D. (1975). Photoperiodism in plants, McGraw Hill

Wynne, M. J. (1969). Life history and systematic studies of some Pacific North American Phaeophyceae (brown algae). Univ. Calif. Publs. Bot. 50: 1-88

This paper was submitted to the editor; it was accepted for printing on February 3, 1982 